Isle City, in Cape May County. Owing to decomposition the bones were not obtained then, and on later visit to the locality the specimen could not be found.

In addition to the above species I have secured since 1908 the following cetaceans at or near Sea Isle City; these are now in the collections of the Academy of Natural Sciences of Philadelphia: Globicephala brachyptera Cope, Kogia breviceps DeB., Mesoplodon densirostris DeB., and Tursiops truncatus Mont.

The Academy of Natural Sciences WM. J. Fox

OF PHILADELPHIA

Note.-Since the above was written one of the fish-pound crews at Sea Isle City brought in on September 25, 1915, seven live specimens of Delphinus delphis.

\section{THE FUR SEAL REPORT}

To the Editor of Science: At pages 41, 14 and 57 of the fur seal report of Messrs. Osgood, Preble and Parker for 1914, Senate Document No. 980, recently published, occur important statistical tables giving enumerations of the different classes of seals for 1912, 1913 and 1914, conclusions and inferences from which affect vitally the report as a whole. The source of the figures for 1912 and 1913, which could only have been obtained from the field notes and unpublished reports of the writer now in the hands of the commissioner of fisheries at Washington, is not indicated and in the paragraph of general acknowledgment at page 17 credit to former workers is limited to "printed reports."

George Archibald Clark

Stanford University, CaLIF., November 19, 1915

\section{ROGER BACON AND GUNPOWDER}

Is his paper "Roger Bacon and Gunpowder" contributed to the "Roger Bacon Commemoration Essays" (edited by A. G. Little, Oxford, 1914), Colonel Hime tries to prove Roger Bacon the inventor of gunpowder by the method employed to prove Francis Bacon the author of Shakespere's plays-a cipher. Since other contributors to the same volume refer favorably to this effort (Mr. A. G. Little, p. 395, calls it an "ingenious explanation" and Mr. Patterson Muir, p. 301, says that "Colonel Hime establishes a large probability" in its favor), it may be well to note some points against it quite apart from the merits of the cipher itself.

In the first place, the cipher is based upon chapters of the "Epistola de secretis operibus naturæ et de nullitate magiæ" not found in the early manuscript of that work and considered doubtful by Charles in his work on Roger Bacon. Indeed, the opening phrases of two chapters, "Transactis annis Arabum sexcentis et duobus," and "Annis Arabum 630 transactis" suggest their source.

Secondly. Roger Bacon openly alludes to gunpowder in 1267 in his "Opus Tertium" as already in common use in children's toy explosives. Therefore Colonel Hime has to date the "De secretis" at 1248, and to hold that Bacon was at that time "driven to employ cryptic methods by fear of the Inquisition" (p. 334), but that by 1267

circumstances had totally changed in the lapse of years; the composition of gunpowder .... had been divulged, and the first use made of the deadly mixture was for the amusement of children (p. 321).

But is there any good reason for dating the "De secretis" in 1248? Much of it sounds like a brief popular compilation from Bacon's three works of 1267-8 concocted by some one else later; compare, for instance, the first paragraph of the sixth chapter of the "De secretis" with Duhem, "Un fragment inédit de l'Opus Tertium," pp. 153-4 and Little, "Part of the Opus Tertium," 50-51. The dedication of the "De secretis" to William, Bishop of Paris, who died in 1249, occurs first in the late edition of 1618 and has not been found by Little in any manuscript.

Then the inquisition bug-a-boo is negligible. Has any one ever shown that the inquisition punished a practical invention? It was not for having invented the telescope that Galileo was persecuted. Moreover, Galileo's was an exceptional case, and it can not be shown that in the thirteenth century the church persecuted men of science. Rather, popes and prelates were their patrons. 
But even if we admit that Bacon wrote the "De secretis" as we have it in 1248 and was at that time afraid of the Inquisition, the question remains: why in 1267-8, when mentioning the explosive in those works in which he made such desperate efforts to secure the pope as his patron and boasted repeatedly of his own superiority to his contemporaries, did he not claim the credit of the invention which he had set forth in cipher twenty years before? The simple answer is: it was not his invention.

One instance must be added to show how Colonel Hime misinterprets the text of the "De secretis". in his eagerness to smell powder everywhere. He writes (p. 324):

Now, towards the end of Chap. X., Bacon speaks without disguise of charcoal under the name of the wood from which it is made, and mentions the two trees, hazel and willow, which give the best. $\mathrm{He}$ significantly adds that when charcoal is added to proper proportions of certain other substances, something noteworthy happens. Since, then, charcoal is one of the subjects of these two chapters, it becomes all the more probable that saltpeter forms another.

In a note Hime adds the Latin of the passage in question:

Si vero partes virgulti coryli aut salicis multarum justa rerum serie apte ordinaveris, unionem naturalem servabunt: et hoc non tradas oblivioni, quia valet ad multa.

Let us note first that these last words do not mean, "something noteworthy happens," but "don't forget this, because it's valuable." Thus the true wording does not in the least suggest an explosion, as Colonel Hime's translation does. Secondly, the words partes virgulti coryli aut salicis probably do not denote charcoal but twigs or rods of hazel or willow, as they do in Bacon's account of the experiment performed by magicians with a split hazel rod. It occurs both in the "Opus Maius" (Bridges, II., 219) and "Opus Tertium" (Little, 49-50; Duhem, 153); I quote the latter.

Unde magici accipiunt virgas coruli et salicum, et dividunt eas secundum longitudinem, et faciunt eas distare secundum quantitatem palmae, et addunt carmina sua, et coniungunt partes divise; sed non propter carmina, sed ex naturali pro- prietate. (Wherefore magicians take rods of hazel and willow, and divide them lengthwise, and hold them the breadth of a palm apart, and add their charms, and the divided parts come together; but not on account of the charms, but from their very natures).

Thirdly, it is probably precisely this hazelrod experiment to which the writer of the passage quoted by Hime refers. Multarum justa rerum serie ordinaveris seems a hurried equivalent for the more specific directions in the passages in the Opus Maius and Opus Tertium, and this bears out what I have already suggested, that the $D e$ secretis may be in part at least a brief popular compilation from Bacon's other works. Finally, the phrase unionem naturalem servabunt applies better to the bending together in the middle of two halves of a split hazel rod held apart at the ends than it does to a mixture of saltpeter, charcoal and sulphur.

And now what becomes of Colonel Hime's assertion, "Since therefore charcoal is one of the subjects of these two chapters, it becomes all the more probable that saltpeter forms another"? We may alter it to read thus: since charcoal is not a subject of either of these chapters, it becomes all the more improbable that a method of refining saltpeter is disclosed in them in cipher.

WESTERN RESERVE UNIVERSITY

\section{LYNN THORNDIKE}

\section{SCIENTIFIC BOOKS}

\section{A Meteorological Treatise on the Circulation} and Radiation in the Atmospheres of the Earth and of the Sun. By Frank $\mathrm{H}$. Bigelow, M.A., L.H.D., Professor of Meteorology in the U. S. Weather Bureau, 18911910, and in the Argentine Meteorological Office since 1910. New York, John Wiley and Sons, Inc., 1915. Pp. xi +431.78 figures in the text.

This volume is an elaboration of the papers on atmospheric thermodynamics which Professor Bigelow published in the American Journal of Science for December, 1912, and March, 1913 , with additions on the laws of storms, on solar constant of radiation; on atmospheric 